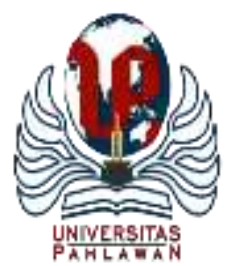

Edukatif : Jurnal Ilmu Pendidikan Volume 4 Nomor 1 Tahun 2022 Halm 1263 - 1273

EDUKATIF: JURNAL ILMU PENDIDIKAN

Research \& Learning in Education

https://edukatif.org/index.php/edukatif/index

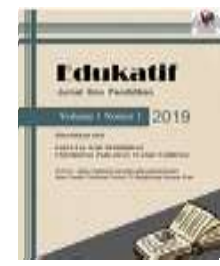

\title{
Teks Ritual Letu Umne Tradisi Pengerjaan Rumah pada Etnik Flores Timur Nusa Tenggara Timur
}

\author{
Veronika Genua ${ }^{1 凶}$, Alexander Bala ${ }^{2}$ \\ Universitas Flores, Indonesia ${ }^{1,2}$ \\ E-mail : nikaruing1971@ gmail.com ${ }^{1}$, naradiring@ gmail.com $^{2}$
}

\begin{abstract}
Abstrak
Tujuan dari penulisan ini adalah untuk memaparkan khazanah teks ritual letu umn pada etnik Flores Timur. Ritual letu umne merupakan ritual menutup lubang tanah yang telah digali untuk membuat rumah tempat tinggal etnik tersebut. Ritual tersebut tetap dijalankan sebagai warisan dari pada leluhur secara turun temurun dan tetap dilaksanakan hingga saat ini. Rumusan masalah yang diangkat pada tulisan ini adalah;1) bagaimanakah bentuk khazanah teks ritual adat letu umne pada etnik Flores Timur NTT; 2) bagaimanakah fungsi khazanah teks ritual adat letu umne pada etnik Flores Timur NTT; 3) bagaimanakah makna khazanah teks ritual adat letu umne pada etnik Flores Timur NTT. Tujuannya adalah untuk menemukan dan mendeskripikan bentuk, fungsi dan makna khazanah teks ritual letu umne pada etnik Flores Timur. Metode yang digunakan adalah deskriptif kualitatif untuk memaparkan teks ritual letu umne Penelitian tersebut menunjukkan bahwa terdapat khazanah kebahasaan dalam kajian linguistik yakni bentuk morfologi yang meliputi nomina, verba, pronomina, adverbial, dan numeralia. Untuk fungsi bahasa meliputi fungsi interpersonal dan fungsi kekerabatan, sedangkan makna yag terkandung dalam tek meliputi makna religius, perlindungan dan makna simbol seperti tuak "moke", dan braha "kapas".
\end{abstract}

Kata Kunci: Teks, letu umne, ritual, tradisi.

\begin{abstract}
The purpose of this paper is to describe the treasures of the letu umn ritual text on the East Flores ethnicity. The letu umne ritual is a ritual to cover a hole in the ground that has been dug to make a house for the ethnic group to live in. The ritual is still carried out as a legacy from the ancestors from generation to generation and is still carried out today. The formulation of the problems raised in this paper are; 1) what is the form of the treasures of the traditional letu umne ritual text on the East Flores ethnicity of NTT; 2) what is the function of the traditional ritual text of letu umne in the East Flores ethnicity of NTT; 3) what is the meaning of the traditional letu umne ritual text for the East Flores ethnicity of NTT. The aim is to find and describe the form, function and meaning of the treasures of the letu umne ritual text on the East Flores ethnicity. The method used is descriptive qualitative to describe the ritual text of letu umne. The research shows that there are linguistic treasures in linguistic studies, namely morphological forms which include nouns, verbs, pronouns, adverbs, and numerals. The language function includes interpersonal functions and kinship functions, while the meaning contained in tek includes religious meaning, protection and the meaning of symbols such as tuak "moke", and braha "cotton".
\end{abstract}

Keywords: Text, letu umne, ritual, tradition

Copyright (c) 2022 Veronika Genua, Alexander Bala

$\square$ Corresponding author

Email : nikaruing1971@gmail.com

DOI : https://doi.org/10.31004/edukatif.v4i1.2094

ISSN 2656-8063 (Media Cetak)

ISSN 2656-8071 (Media Online)

Edukatif : Jurnal Ilmu Pendidikan Vol 4 No 1 Tahun 2022 p-ISSN 2656-8063 e-ISSN 2656-8071 
1264 Teks Ritual Letu Umne Tradisi Pengerjaan Rumah pada Etnik Flores Timur Nusa Tenggara Timur Veronika Genua, Alexander Bala

DOI: https://doi.org/10.31004/edukatif.v4i1.2094

\section{PENDAHULUAN}

Setiap etnik atau daerah tentunya memiliki tradisi atau adat istiadat setempat. Setiap tradisi tentu menggunakan bahasa untuk mengkominkasikan semua ide atau hal apa saja yang akan dilaksanakan. Bahasa tersebut memiliki peranan penting dalam kehidupan sehari-hari untuk dapat berinteraksi antar etnik yang satu dengan yang lainnya. Kenyataan yang dihadapi saat ini terlihat bahwa semua orang dalam kehidupan sehari-hari selalu mempraktekan bahasa baik dalam komunikasi secara lisan maupun tulisan. Orang menyadari bahwa interaksi dalam segala kegiatan dalam etnik akan lumpuh tanpa bahasa. Begitu pula melalui bahasa, kebudayaan suatu bangsa dapat dibentuk, dibina, dan dikembangkan serta dapat diturunkan kepada generasi-generasi mendatang (Fauzan 2021)

Bahasa sebagai alat komunikasi verbal lisan hanya dimiliki manusia, karena hanya manusia yang memiliki bahasa. Tidak ada manusia yang hidup tanpa bahasa. Manusia dan bahasa bagai benang dan jarum. Jadi, dimana ada bahasa di situ ada manusia, dan atau sebaliknya dimana ada manusia, di situ ada bahasa. Bahasa merupakan alat komunikasi yang digunakan manusia dalam kehidupan sehari-hari untuk menyampaikan pesan dan maksud penutur kepada lawan tutur. Peran bahasa sangat penting bagi kehidupan manusia. Begitu pentingnya peran bahasa maka setiap orang dituntut untuk dapat menguasai atau memiliki bahasa dan memahami bahasa yang disampaikan. Bahasa merupakan instrument atau sarana berpikir dan bertindak yang digunakan manusia untuk saling berkumnikasi dan berinteraksi secaralisan maupun tulisan, maupun gerakan badan atau isyarat (Eiilerz 1995).

Bahasa daerah adalah sebuah komponen kebudayaan. Bahasa daerah tidak hanya berfungsi sebagai salah satu unsur budaya lokal, jati diri etnik penutur, lambang kebanggaan daerah, fakta kebhinekaan dan keragaman budaya bangsa, serta dapat menambah khazanah budaya nasional. Selain itu juga bahasa digunakan sebagai sarana untuk memahami dan menginformasikan makna dan nilai berbagai fenomena sosial budaya etnik (Pampe 2009). Bahasa daerah tidak dapat dipisahkan dari kehidupan etnik itu sendiri, karena bahasa daerah disajikan dan dimanifestasikan untuk kepentingan etnik. Dengan demikian dapat dikatakan bahasa daerah merupakan milik etnik daerah.

Bahasa memiliki peranan penting dalam kehidupan etnik Hal tersebut dikarenakan bahasa merupakan alat pemersatu dalam kehidupan etnik. Selain itu, bahasa digunakan sebagai alat untuk mnyampaikan maksud dan pikiran seseorang untuk dapat berkomunikasi dengan orang lain. Pada dasarnya, manusia adalah makluk sosial. Artinya manusia diciptakan untuk hidup bersama dan berdampingan dengan manisia yang lain. Manusia harus hidup bersama untuk memenuhi kebutuhan, antara yang satu dengan yang lainnya. Interaksi ini terlihat jelas melalui pemakaian bahasa. Bahasa daerah menjadi media utama etnik di pedesaan dalam berinteraksi. Bahasa daerah merupakan milik etnik secara kolektif. Etnik mengggunakan bahasa daerah untuk bertindak, berpikir dan mengungkapkan apa yang ada dalam dirinya.

Sebagai alat komunikasi bahasa merupakan saluran perumusan maksud seseorang melahirkan perasaan dan memungkinkan seseorang menciptakan kerja sama dengan sesama warga. Bahasa mengatur berbagai aktivitas keetnikan, merencanakan dan mengarahkan masa depan kita. Bahasa juga memunginkan manusia menganalisa masa lampaunya untuk memetik hasil- hasil yang berguna bagi masa kini dan masa yang akan datang (Keraf 2004).

Menurut (Pampe 2009) bahasa daerah tidak dapat dipisahkan dari kehidupan etnik itu sendiri, karena bahasa daerah disajikan dan dimanifestasikan untuk kepentingan etnik. Dengan demikian dapat dikatakan bahasa daerah merupakan milik etnik daerah. Manusia pada dasarnya ialah makluk sosial. Artinya manusia diciptakan untuk hidup bersama dan berdampingan dengan manisia yang lain. Manusia harus hidup bersama untuk memenuhi kebutuhan, antara yang satu dengan yang lainnya. Interaksi ini terlihat jelas melalui pemakaian bahasa. Bahasa daerah menjadi media utama etnik di pedesaan dalam berinteraksi. Bahasa daerah merupakan milik etnik secara kolektif. Etnik mengggunakan bahasa daerah untuk bertindak, berpikir dan 
1265 Teks Ritual Letu Umne Tradisi Pengerjaan Rumah pada Etnik Flores Timur Nusa Tenggara Timur Veronika Genua, Alexander Bala

DOI: https://doi.org/10.31004/edukatif.v4i1.2094

mengungkapkan apa yang ada dalam dirinya. Pemberian pengetahuan yang berbudaya lokal (Nur, Fadhilah and Rahmawati 2020).

Menurut Haugen (Ola 2013:133) meyatakan bahwa bahasa hadir dalam pikiran penuturnya dan bahasa hanya dapat berfungsi ketika penuturnya dapat menghubungkan para penutur satu sama lain dan dapat menghubungkan bahasa dengan alam. Sebagai alat komunikasi bahasa merupakan saluran perumusan maksud seseorang melahirkan perasaan dan memungkinkan seseorang menciptakan kerja sama dengan sesama warga. Bahasa mengatur berbagai aktivitas keetnikan, merencanakan dan mengarahkan masa depan kita. Bahasa juga memunginkan manusia menganalisa masa lampaunya untuk memetik hasil- hasil yang berguna bagi masa kini dan masa yang akan datang (Keraf 2004).

Bahasa daerah dapat dikenali melalui suatu daerah dan kebudayaan tertentu. Di sisi lain, bahasa daerah dapat membantu seseorang memahami kehidupan kelompok etnik yang memakai bahasa daerah tersebut. Bahasa bersifat unik artinya tiap bahasa mempunyai sistem yang khas dan tidak harus ada dalam bahasa lain. Selain sebagai sarana komunikasi sehari-hari bahasa daerah Lamaholot di Flores Timur merupakan sarana teks adat yang digunakan dalam ritual letu umne tradisi pembuatan rumah adat itu pada hakekatnya tidak dituturkan sebagai alat komunikasi biasa dalam kehidupan sehari-hari tetapi diungkapkan khusus dalam ritual-ritual adat.

Apresiasi terhadap kebudayaan adalah penilaian atau penghargaan terhadap nilai-nilai yang terkandung dalam setiap kebudayaan yang merupakan hasil cipta, rasa, dan karsa manusia. Kebudayaan bukanlah sesuatu yang bersifat individual, tetapi merupakan milik bersama dalam suatu kelompok warganya milik bersama. Selanjutnya terdapat sejumlah pola pikir dan dapat dikembangkan melalui proses belajar. Hal tersebut wajib dimiliki bersama menjadi sesuatu yang khas dan unik, bagi setiap pemiliknya. Proses penciptaan kebudayaan merupakan proses pencerdasan yang hasilnya mampu meningkatkan harkat dan martabat bangsa dan negara. Jika anak bangsa dibiarkan menjadi user hasil karya budaya asing, maka yang terjadi adalah proses keterasingan atau modernisasi semu (Rahyono 2015: 59). Tuturan adat erat kaitannya dengan perkembangan budaya berpikir dan bertindak, etnik pendukung dan pelakunya. Di samping itu tuturan adat dapat pula digunakan sebagai sarana pendidikan bagi generasi muda melalui etnik setempat. Salah satu ritual yang tetap dilaksanakan oleh etnik Flores Timur yakni ritual Letu umne pada saat pembuatan rumah dengan menggunakan bahasa daerah Lamaholot. Sudah menjadi suatu tradisi bagi bahwa dalam teks ritual adat terkandung berbagai makna yang terkandung di dalamnya. Upacara rumah biasanya dilaksanakan setelah diadakan renovasi bangunan atau membuat rumah baru. Upacara ini merupakan suatu pesta besar yang harus dihadiri oleh seruruh kerabat dan keluarga yang berasal dari rumah adat tersebut (Isu 2021).

Bahasa daerah dapat dikenali melalui suatu daerah dan kebudayaan tertentu. Memperkenalkan suatu budaya tradisi adat istiadat dengan tujuan untuk membangun kecintaan setiap masyarakat akan budaya yang dimilikinya. Selain itu setiap masyarakat berusaha untuk tetap melestarikanya seperti tarian atau pun pembuatan rumah adat (Riyanti, Irfani, and Prasetyo 2022). Di sisi lain mengenai bahasa daerah dapat membantu seseorang memahami kehidupan kelompok etnik serta pola tingkah laku yang dapat mengatur etnik tersebut. Selain sebagai sarana komunikasi sehari-hari bahasa merupakan sarana teks adat yang dapat digunakan dalam ritual letu umne " pengerjaan rumah" sebagai tempat huni setiap warganya. Pengerjaan rumah berkaitan dengan kebudayaan yang merupakan aspek yang paling inti dalam kehidupan manusia. Segala hirarki kajian bahasa termasuk dalam bidang antropolinguistik yang membicarakan tentang bahasa dan budaya (Sibarani 2015).

Di tengah peradaban yang begitu pesat, setiap etnik selalu berpegang teguh pada warisan dari para leluhur yang telah diwariskan secara turun temurun. Rasa kekeluargaan dan kebersamaan selalu dipupuk oleh setiap etnik yang berada pada wilah tersebut (Hasanah and Sukmawan 2021). Berdasarkan pandangan yang disampaikan tersebut dapat dikatakan bahwa etnik Flores Timur tetap mewariskan tradisi yang diturunkan oleh leluhur pada zaman dahulu. 
1266 Teks Ritual Letu Umne Tradisi Pengerjaan Rumah pada Etnik Flores Timur Nusa Tenggara Timur Veronika Genua, Alexander Bala

Kebudayaan yang diturunkan sangat erat kaitan dengan teks ritual yang disesuaikan dengan perkembangan budaya berpikir dan bertindak suatu etnik. Pengajaran budaya melalui suatu cerita memiliki pesan moral yang sudah dilakukan ribuan tahun lalu. Cerita yang sama tersebut dapat diteruskan dari generasi ke generasi dan mengalami distori sehingga tak lagi diketahui kebenarannya (Angeline 2015). Selain cerita, tuturan adat dapat pula digunakan. Hal tersebut sudah menjadi suatu tradisi dalam ritual adat digunakan. Setiap teks adat yang mengungkapkan perasaan, perwujudan sikap etnik dalam hidupnya, karena etnik Flores Timur yakin melalui ritual tersebut para leluhur mengabulkan keinginan dan harapan yang disampaikan. Dalam ritual letu umne pada saat pembuatan rumah terdapat makna tuturan adat yang dituturkan oleh tua adat. Setiap teks tersebut terkandung berbagai makan di dalamnya yang mempunyai dampak bagi etnik setempat. Ritual Letu umne pada saat pembuatan rumah terdapat bentuk tuturan adat yang dituturkan oleh Tua Adat atau juru bicara. Teks dalam pembuatan rumah dapat dijadikan sebagai unsur penting untuk pembinaan dan pengembangan bahasa dapat dilakukan dengan berbagai cara. Salah satunya adalah penelitian dan inventarisasi bahasa secara khusus bahasa daerah (Muhidin 2015).

Selain sebagai sarana komunikasi sehari-hari, bahasa juga sebagai sarana tuturan adat yang dapat digunakan dalam ritual-ritual adat misalnya, ritual-ritual mohon berkat hasil panen, ritual perkawinan serta ritual-ritual resmi lainnya. Ritual letu umne pada saat pembuatan rumah merupakan salah satu ritual yang sering dilakukan etnik Flores Timur ketika sebuah rumah siap untuk dihuni. Tuturan dalam ritual letu umne pada saat pembuatan rumah merupakan sarana ekspresi dalam hubungan adat untuk bersyukur kepada sang pencipta dan kepada nenek moyang sekalian sebagai acara syukuran karena telah menyelesaikan pembangunan rumah dan sebagai tanda bahwa rumah tersebut telah layak untuk dihuni. Ritual letu umne pada saat pembuatan rumah juga secara turun temurun dilakukan etnik Flores Timur sangat penting dan sebagai bukti untuk pemahaman generasi muda agar lebih mengenal dan mengetahui setiap makna teks yang terkandung di dalamnya. Perencanaan berbasis lokal untuk menjawan tantangan global yang dapat mengkikis pemahaman masyarak tentang budaya dan adat istiadat (Umri , Ulili and Hadiyanto 2021).

Berikut ini salah satu teks adat letu umne dalam mengerjakan rumah adat pada etnik Flores Timur.

Ina ratu rera wulan,

Tuhan ratu yang maha bulan

Tuhan yang Maha Kuasa

ama nini tanah ekan,

Bapak ibu tanah bumi

Para leluhur di bumi

teti modi lodo hau,

di atas dengan turun datang

Datanglah di tengah kami

Lali modi gere haka,

Teks yang dipaparkan tersebut bermakna religius, yakni memohon kepada Tuhan Yang Maha Kuasa dan juga meneghadirkan leluhur untuk bersama merestui dan meyaksikan pengerjaan rumah tempat hunian dari etnik setempat. Teks yang dituturkan oleh tua adat setempat agar proses yang akan dilakukan dapat berjalan dengan lancar. Sikap mempertahankan budaya menggambarkan kepatuhan masyarakat terhadap warisan leluhur (Manek 2021).

Hal tersebut juga sebagai bahan pembelajaran dari generasi penerus untuk dapat mengetahuinya agar budaya setempat tetap diwariskan agar tidak punah. Kenyataan yang terjadi saat ini, pada umumnya generasi penerus atau generasi muda kurang mempedulikan tentang budaya daerah setempat. Generasi muda saat ini, begitu sibuk dengan permainan game secara online, sibuk catting, tik tok, dan berbagai media sosial lainnya. 
1267 Teks Ritual Letu Umne Tradisi Pengerjaan Rumah pada Etnik Flores Timur Nusa Tenggara Timur Veronika Genua, Alexander Bala

DOI: https://doi.org/10.31004/edukatif.v4i1.2094

Untuk itu penelitian ini perlu dipublikasikan untuk pengetahuan generasi selanjutnya. Selain itu dapat menjadi bahan pembelajaran dalam muatan lokal bagi para siswa di sekolah untuk mengenal dan memahami pesan dan makna yang terkandung dalam budaya daerah. Permasalahan yang diangkat dalam tulisan ini adalah 1) bagaimanakah bentuk khazanah teks ritual letu umne pada etnik Flores Timur, 2) bagaimanakah fungsi khazanah teks ritual letu umne pada etnik Flores Timur. 3) bagaimanakah makna khazanah teks ritual letu umne pada etnik Flores Timur Tujuannya untuk menemukan dan mendeskripsikan bentuk dan makna khazanah teks ritual letu umne pada etnik Flores Timur. Metode yang digunakan dalam kajian tersebut yakni deskripsi kualitatif untuk memaparkan khazanah teks letu umne serta bentuk dan makna yang terkandung didalamnya. Teknik yang digunakan yakni catat, wawancara, dan dokumentasi.

Teori yang digunakan dalam tulisan ini yakni teori linguistik kebudayaan. Linguistik kebudayaan/linguistik budaya membuka cakrawala baru untuk mencari tahu lebih lanjut, apa yang ada di dalamnya, jati diri, prinsip, metode, dan cara kerjanya. Linguistik kebudayaan sesungguhnya adalah bidang ilmu interdisipliner yang mengkaji hubungan kovariatif antara struktur bahasa dengan kebudayaan suatu etnik menurut Mbete dalam (Genua 2019). Berdasarkan teori tersebut terdapat kebaruan dalam penelitin yakni terdapat makna sosiologis yakni hubungan masyarakat dengan para leluhur yang diyakini ada namu tidak terlihat secara kasat mata. Penelitian terdahulu tentang teks dalam suatu tarian adat namun, tulisan ini berkaitan dengan teks yang berkaitan dengan pengerjan rumah yang dihuni masyarakat. Penelitian ini sangat penting dilakukan dalam kaitan dengan budaya agar masyarakat secara khusus generasi muda dapat memahami makna yang terkandung dalam teks adat letu umne tersebut.

\section{METODE PENELITIAN}

Penelitian yang digunakan dalam kajian ini yakni penelitian deskriptif kualitatif untuk mendeksripsikan secara lengkap tentang teks adat yang dituturkan pada saat pengerjan rumah dan proses yang dilakukan. Penelitian ini dilaksanakan di Flores Timur Flores NTT tentang teks pengerjaan rumah yakni letu umne. Data yang digunakan yakni data lisan tentang teks adat yang dituturkan oleh tua adat setempat. Sumber data diperoleh dari tua adat setempat, budayawan, tokoh etnik dan orang yang paham tentang budaya dan adat istiadat setempat. Teknik dalam pengumpulan data yakni penelitian lapangan dengan dengann melakukan wawancara dengan narasumber untuk mendapatkan informasi tentang teks adat dan makna dibalik setiap teks letu uтne dituturkan oleh narasumber. Setelah melakukan wawancara, data tersebut ditranskripkan ke dalam bahasa Indonesia untuk menentuk bentuk,dan makna yang terkandung didalamnya.

Selain melakukan wawancara, penulis mencatat hal-hal penting yang berkaitan dengan teks adat dalam pengerjaan rumah. Selanjutnya menggunakan teknik rekam dan dokumentasi untuk untuk memperoleh data secara keseluruhan yang berkaiatan dengan tradisi setempat. Analisis data dengan menggunakan model analisis interaktif yang dikembangkan oleh (Miles, M., \& Huberman 1992:16) ada empat komponen yang dilakukan dalam model ini, yakni pengumpulan data, reduksi data display data, menarik kesimpulan atau verifikasi. Komponen tersebut dilakukan untuk menganalisis data secara terperinci.

\section{HASIL DAN PEMBAHASAN PENELITIAN}

Teks letu umne merupakan ritual yang dilakukan menutup lubang tanah yang digali pada saat pembuatan rumah untuk dihuni oleh pemiliknya. Setiap teks yang disampaikan dalam ritual adat tersebut dianalisis dari bentuk, fungsi dan makna yang terkandung didalamnya yang dapat dijadikan sebagai bahan pembelajaran terhadap bahasa.

Berikut ini akan dipaparkan bentuk, fungsi, dan makna dalam teks letu umne tradisi etnik Flores Timur. 
1268 Teks Ritual Letu Umne Tradisi Pengerjaan Rumah pada Etnik Flores Timur Nusa Tenggara Timur Veronika Genua, Alexander Bala

DOI: https://doi.org/10.31004/edukatif.v4i1.2094

\section{Bentuk Teks adat Letu Umne pada Etnik Flores Timur}

Setiap teks memiliki bentuk yang terkandung di dalamnya. Bentuk teks letu umne dapat dikaji dari bentuk mikrolinguistik berikut ini. Ciri Morfologi dalam teks adat dalam Ritual Letu umne dapat dipaparkan berikut ini.

a. Nomina

Nomina merupakan kelas kata yang berfungsi sebagai subjek dan objek yang yang mengacu pada orang, benda dan hal lain yang dibendakan. Nomina merupakan kelas kata yang berfungsi sebagai subjek atau objek dari klausa. Nomina berpadanan dengan orang atau benda atau hal lain yang dibendakan (Kridalaksana, 2008:163). Data nomina dapat dilihat pada kata /frasa yang bercetak tebal berikut.

Tahap Pertama Soro Nei "Pemberian sesajian kepada nenek moyang"

Data (1)

Nene moyang wahan kae, pi ume lamak mio

Nenek moyang sudah semua, ini makanan kamu

Para leluhur terimalah semua pemberian kami

Arak, teluk, taha, no braha ume lamak mio

Moke, telur, beras, dan kapas makanan kamu

Moke, telur, beras, dan kapas kami sajikan

Maja ge menu hama-hama

Berdasarkan data (1) nomina seperti frasa nenek moyang, ume lamak termasuk nomina majemuk. Frasa nomina nenek moyang merupakan nomina orang yang telah meninggal sedangkan dan ume lamak bentuk makanan yang telah disajikan peda para leluhur. Selanjutnya nomina Arak, teluk, taha, dan braha bahan sesajen yang akan dipersembahkan kepada para leluhur.

Kelompok nomina selanjutnya terlihat pada kalimat berikut ini .

Hone no'o lango kae, wani no'o uli kae

Membuat dengan rumah, sudah membuat dengan tempat istirahat

Sudah membangun rumah kediaman, sudah membuat tempat peristirahatan

Lango punadike kae, uli liput sare kae

Rumah sudah jadi, tempat istirahat sudah dibuat dengan baik

Rumah kediaman sudah dibangun

Nomina dalam teks tersebut terlihat pada kata yang bercetak tebal yakni lango 'rumah' lango 'merupakan suatu tempat yang akan dihuni oleh pemilik rumah pada etnik setempat. Selanjutnya data lain yang menunjukkan nomina dapat dilihat pada kalimat berikut ini.

Gute mala witi sora pile mala wawe wajo

Ambil ambil kambing itu, pilih ambil babi itu

Ambillah kambing dan babi itu

Penggunaan kata benda witi 'kambing' dan wawe 'babi'

terlihat pada kalimat sebagai berikut:

Data tersebut dikatakan bahwa nomina witi 'kambing' dan wawe 'babi' berkategori nomina karena merupakan hewan korban yang akan di ambil darah untuk dioles pada tiang rumah dan hatinya untuk disajikan kepada nenek moyang.

b. Verba

Verba merupakan sebuah kata yang menyatakan keadaan, perbuatan atau tindakan yang dapat berubah bentuk dengan sistem pengkonjungsian dalam kalimat dan berfungsi sebagai predikator. Verba dalam teks letu umne menggambarkan perbuatan, keadaan, atau proses yang dilakukan pada saat ritual mbama berlangsung. 
1269 Teks Ritual Letu Umne Tradisi Pengerjaan Rumah pada Etnik Flores Timur Nusa Tenggara Timur Veronika Genua, Alexander Bala

DOI: https://doi.org/10.31004/edukatif.v4i1.2094

Verba yang dimaksud yakni merupakan kata yang menjelaskan suatu kegiatan atau pekerjaan. Contoh verba dapat dilihat pada kata/ frasa yang bercetak tebal pada kalimat berikut ini.

\section{Maja ge menu hama-hama}

Panggil makan sama-sama

Mengajak semua leluhur dimanapun berada supaya bisa makan bersama'

Verba pada teks tersebut terlihat pada kata yang bercetak tebal yakni maja 'panggil' Kata maja 'mengajak para leluhur untuk datang berkumpul makan bersama.

Verba selanjutnya terdapat pada kalimat berikut ini .

Hone no'o lango kae, wani no'o uli kae

Membuat sebuah rumah, membuat tempat istirahat

membangun rumah kediaman sebagai tempat tinggal

Verba dalam teks tersebut yakni hone 'membuat' dan wani 'membuat' merupakan verba berderet yang terdapat dalam satu kalimat.

Pana nala dute waen, dei nala jadi ana

Pergi mengambil istri, berdiri melahirkan anak

Pergi mengambil istri, dan melahirkan anak-anak

Pemakaian kata 'dute' 'ambil' nala 'ambil' dei nala ' berdiri melahirkan' pada kalimat tersebut menggambarkan atau menyatakan untuk mengambil istri dan sudah melahirkan anak-anak. Verda pada kaliat tersebut merupakan kelompok verba berderet.

c. Numeralia

Numeralia merupakan kelas kata atau kategori yang dapat mendampingi nomina dalam konstruksi sintaksis. bilangan adalah kata yang menyatakan jumlah, urutan dan tingkatan suatu benda (Djajasudarma, 2010: 49). Numeralia pada teks letu umne dapat dilihat pada teks atau kalimat beriku ini. Kata bilangan terdapat terdapat pada kata yang bercetak tebal berikut ini.

Puluh pito : tujuh puluh bilang

Puluh lema : lima puluh

Numeralia puluh pito 'tujuh puluh' dan numeralia puluh lema 'lima puluh' merupakan numeralia utama atau disebut denan bilangan penuh. Secara lengkap numeralia dapat dilihat pada kalimat berikut ini.

Teti wan puluh pito, lali wade puluh lema

dan puluh lema 'lima puluh' dari tuturan

Diatas tujuh puluh lapis, Dibawah lima puluh lapis

Yang berada dilangit yang ketujuh puluh, dan dibawah lapisan bumi kelima puluh'. Penggunaan kata puluh pito 'tujuh puluh' tersebut mengandung arti bahwa lapisan keturunan yang sudah banyak.

\section{d. Pronomina}

Pronomina atau kata ganti adalah jenis kelas kata yang menggantikan nomina atau frasa nomina. Teks letu umne juga memiliki beberapa pronominal baik dalam satu kalimat maupun pada kalimat lainnya. Data pronomina dalam teks ritual letu umne yakni kami "kami" dan miи "kamu" dapat dilihat pada kalimat berikut ini.

Kaka pia tobo lewo kame

kaka sini duduk kampong 2TGL

kaka duduk di kampung kami

Pronomina atau kata ganti kami merupakan kata ganti orang pertama jamak. Kata ganti tersebut menunjukkan bahwa guyub kultur setempat menggunakan kata kami 'kami”yakni etnik setempat untuk duduk di kampung untuk menempati rumah yang sudah disiapkan. 
1270 Teks Ritual Letu Umne Tradisi Pengerjaan Rumah pada Etnik Flores Timur Nusa Tenggara Timur Veronika Genua, Alexander Bala

DOI: https://doi.org/10.31004/edukatif.v4i1.2094

Berikut kata pia 'sini" menunjukkan pronominal demontrativa yang digunakan untuk menunjuk suatu tempat tinggal yang baru yaitu di kampung asal.

e. Adverbial

Adverbia merupakan kata yang memerikan verba, adjektiva, preposisi, atau adverbial lain (Kridalaksana, 2009: 2). Adverbia merupakan kata yang menunjukkan atau menjelaskan berlangsungnya suatu peristiwa dalam suatu peristiwa dalam suatu waktu. Data keterangan terlihat pada kata yang bercetak tebal berikut ini.

Teti : di atas sana (keterangan tempat)

Lali : di bawah sana (keterangan tempat)

Lewo : kampung (keterangan tempat)

Kata keterangan teti 'di atas sana' dan lali 'di bawah sana' terdapat dalam tuturan ritual Letu umne kalimat sebagai berikut:

Kata keterangan teti 'di atas' dan lali 'di sana' terdapat dalam tuturan upacara letu tana umne kalimat sebagai berikut:

Teti modilodo hau, lali modi gere haka

Diatas sana juga datang kesini, dibawah sana naik kesini

Turunlah ditengah-tengah kami, dan masuklah juga ditengah-tengah kami

Pemakaian kata teti 'di atas sana' dan lali 'di bawah sana' menunjukkan suatu tempat yang menjadi kediaman nenek moyang.

Data selanjutnya yang menunjukkan adverbial dapat dilihat pada kalimat berikut ini.

Kaka pia tobo lewo kame, bapa pia pae tana kame

Kakak duduk dikampung kami, bapak juga mendiami tanah kami

Kakak mendiami kampung kami, bapak juga mendiami tanah kami'

Dari tuturan tersebut yakni lewo 'kampung' merupakan tempat tinggal untuk semua orang yang mendiami wilayah tersebut yang merupakan pengelompokkan adverbial.

\section{Fungsi Tuturan dalam Upacara Letu Umne}

a. Fungsi Interpersonal

Fungsi interpersonal merupakan fungsi bahasa yang digunakan untuk menjalin dan memelihara hubungan sosial. Hal ini terlihat pada tuturan tahap soro nei yaitu semua leluhur yang telah meninggal diberi arak, teluk, taha, serta braha untuk nenek moyang merupakan suatu bentuk penghargaan dalam menjalin suatu hubungan yang erat agar hubungan itu tidak hanya kepada yang masih hidup, karena nenek moyang sebagai media dalam menyampaikan permohonan kepada Maha Kuasa. Masyarakat atau etnik setempat yakin bahwa segala sesuatu harus bergapang teguh pada peninggalan leluhur yang telah diwariskan secara turun temurun. dan tetap dipertahankan gar tidak punah.(Hasanah and Sukmawan 2021). Hal tersebut dapat dilihat pada fungsi interpersonal pada kutipan kalimat berikut ini.

Nene moyang wahan kae, pi ume lamak mio

Nenek moyang semua, ini makanan kamu

Para leluhur semua terimalah bagianmu ini

Maja ge menu hama-hama

Panggil makan sama-sama

Panggilah semua leluhur dimanapun berada supaya bisa makan bersama

Kalimat tersebut mengandung pengertian bahwa suatu bentuk penghargaan dalam menjalin suatu hubungan yang erat agar hubungan itu tidak hanya kepada yang masih hidup, karena nenek moyang merupakan media dalam menyampaikan permohonan kepada Tuhan. 
1271 Teks Ritual Letu Umne Tradisi Pengerjaan Rumah pada Etnik Flores Timur Nusa Tenggara Timur Veronika Genua, Alexander Bala

DOI: https://doi.org/10.31004/edukatif.v4i1.2094

\section{b. Fungsi Kekerabatan}

Fungsi kekerabatan secara khusus yang merupakan gambaran hubungan atau kedekatan antara warga masyarakat pewaris kebudayaan tersebut. Fungsi kekerabatan dengan maksud untuk mendorong dan menumbuhkan nilai positif yang sudah mulai merdup dalam masyarakat seperti suka menolong atau berbuat baik (Genua 2013). Kalimat-kalimat yang menyatakan fungsi kekerabatan dapat terlihat pada kalimat berikut ini.

Nene moyang wahan kae, pi ume lamak mio

Nenek moyang semua, ini makanan kamu

Para leluhur semua terimalah bagianmu ini

Maja ge menu hama-hama

Panggil makan sama-sama

Meyapa luluhur untuk makan bersama

Berdasarkan kalimat tersebut menggambarkan sebuah upacara pemberian makan kepada nenek moyang atau leluhur sebagai bentuk jalinan kekerabatan. Selain itu merupakan gambaran hubungan atau kedekatan antara warga masyarakat pewaris kebudayaan tersebut.

\section{Makna Teks Letu Umne pada Etnik Flores Timur}

Setiap teks tentunya terdapat berbagai makna yang terkandung di dalamnya. sama halnya dengan teks letu umne pada etnik Flores Timur. beberapa makna yang terkandung didalamnya dapat dipaparkan berikut ini.

a. Makna Religius

Makna religius merupakan penyampaian permohonan dan syukur kepada Tuhan sebelum melaksanakan kegiatan upacara letu umne tua adat memohon Tuhan dan kepada nenek moyang yang telah meninggal dunia untuk merestui kegiatan letu umne dan sebagai makluk yang lemah dan selalu berharap dan bersandar pada Tuhan seperti terlihat pada kalimat berikut ini.

Ina ratu rera wulan, Ama nini tana ekan

Penguasa matahari dan bulan, penguasa bumi

Tuhan yang maha kuasa dan para nenek moyang

Teti wan puluh pito, lali wade puluh lema

Yang berada dilangit yang ketujuh puluh, dan dibawah lapisan bumi kelima puluh'

Tuturan dalam makna religius di atas mengandung pengertian bahwa Tuhan yang Maha Kuasa dan para leluhur dimana pun berada agar melindungi dan memberi keamanan pada rumah kami. Selain itu sebagai media untuk menjalin hubungan dengan sesuatu yang lebih tinggi yang diyakini sebagai sang pencipta.

\section{b. Makna Perlindungan}

Makna perlindungan ini adalah Tuhan Penguasa Yang Maha Kuasa serta penguasa bumi lindungilah agar rumah kediaman dan tempat peristirahatan yang di bangun dapat memberi ketentraman dan kedamaian kepada kami seisi rumah. Dalam memilih kebiasaan hidup sehari-hari, bahkan dalam hal kecil sekalipun, masyarakat selalu memilih kebiasaan hidup sesuai sesuai dengan pemikirannya. Hal tersebut berkaitan dengan pembuatan rumah rempat tinggal yang dapat memberi perlindungan bagi penghuni didalammnya (Lokanawa 2013). Data tuturan tersebut dapat terlihat berikut ini.

Kaka pia tobo lewo, bapa pia pae tana

Kakak duduk dikampung kami, bapak juga mendiami tanah kami

Kakak mendiami kampung kami, bapak juga mendiami tanah kami

Rumah sudah jadi, tempat istirahat sudah dibuat dengan baik. Rumah kediaman sudah dibangun dengan baik, tempat peristirahatan sudah dibentuk dengan baik. 
1272 Teks Ritual Letu Umne Tradisi Pengerjaan Rumah pada Etnik Flores Timur Nusa Tenggara Timur Veronika Genua, Alexander Bala

DOI: https://doi.org/10.31004/edukatif.v4i1.2094

Kalimat tersebut menyatakan mohon penyertaan pada Tuhan untuk penghuni rumah tempat tinggal yang nyaman dan bahagia.

c. Makna Simbolis

Makna simbol yang dimaksudkan dalam tulisan ini merupakan sarana yang yang akan digunkan sebagai bahan sesajian kepada para leluhur seperti berikut ini moke, telur, beras, dan kapas makan kamu yang bisa kami sajikan (Khoiri 2009). Simbol-simbol dalam upacara yang dilakukan bertujuan sebagai sarana untuk menunjukkan secara semu maksud dan tujuan upacara yang dilakukan oleh masyarakat pendukungnya. Data tersebut yakni berupa arak 'moke', teluk 'telur', taha 'beras', dan braha kapas'. Melambangkan kebersamaan. Kebersamaan dalam hal ini simbol dalam menjamu orang yang datang bertamu sekaligus menjalin relasi dengan sesama baik yang masih hihup maupun dengan para arwah agar hubungannya intim dan erat.

Arak'moke', teluk 'telur', taha 'beras', dan braha 'kapas' sebagai persembahan pada upacara letu umne merupakan simbol dalam menjamu orang yang datang bertamu sekaligus menjalin relasi dengan sesama yang datang bertamu maupun para arwah nenek moyang Tradisi tentang pembuatan simbol litu umne menjadi bagian dalam suatu ritual adat. Terdapat kesesuaian hasil penelitian ini dengan peneitian lainnya yakni setiap ritual memiliki simbol terutama dalam memberikan sesajian atau pengormatan kepada para leluhur . Pemberian makna simbolis dalam kegiatan memiliki peran penting yakni leluhur sebagai perantara.

\section{KESIMPULAN}

Teks letu umne merupakan ritual menutup lubang tanah pada saat membuat rumah baru. Setiap teks dalam ritual letu umne memiliki khazanah kebahasaan yang meliputi bentuk fungsi dan makna yang terkandung dalam setiap teks yang merupakan ciri khas pada etnik Flores Timur NTT. Bentuk teks letu umne memiliki beberapa kategori morfologi yakni kelompok nomina, verba, pronomna, adverbial dan numelaria. Setiap teks memiliki kata, frasa, dan kalimat yang memiliki ciri tersendiri. Selain bentuk, terdapat pula fungsi teks yakni fungsi interpersonal dan fungsi kekerabatan. Selanjutnya, setiap teks memiliki makna yang terkandung di dalam setiap kalimat yakni makna religius, makna, makna perlindungan dan juga makna simbol yang nerupakan sarana yang digunakan selama ritual berlangsung. Salah satu contoh makna kapas putih sebagai bagian dari alat pemersatu anara para lelehur dam masyarakat setempat. Hal tersebut merupakan bagian dari pembejaran agar masyarakat atau generasi penerus dapat memahami serta tetap mempertahankan budaya yang ada sebagai bagian dari budaya adat istiadat.

\section{DAFTAR PUSTAKA}

Angeline, Mia. 2015. "Mitos Dan Budaya." Humaniora 6(2): 190.

Eiilerz, Yosef-Frans. 1995. Berkomunikasi Antara Budaya. Ende: Nusa Indah.

Fauzan. 2021. "Dwifungsi Tuturan Oposisi Dalam Masyarakat Bersosiokultur Jawa." Kembara: Jurnal Keilmuan Bahsa, Sastra, Dan Pengajarannya 7(1): 17-29.

Genua, Veronika. 2013. Nilai Kehidupan Dalam Legenda Rendo Rate Rua Sebagai Jati Diri Masyarakat Kabupaten Ende Ntt.

. 2019. "Teks Sole Oha Tradisi Budaya Guyub Kultur Lembata Flores Ntt.” Retorika 1: 30-41.

Hasanah, Holifatul, And Sony Sukmawan. 2021. "Berbingkai Kemajemukan Budaya, Bersukma Desakalapatra: Selidik Etnografi Atas Tradisi Tengger." Diglosia: Jurnal Kajian Bahasa, Sastra, Dan Pengajarannya 4(1): 79-90. 
1273 Teks Ritual Letu Umne Tradisi Pengerjaan Rumah pada Etnik Flores Timur Nusa Tenggara Timur Veronika Genua, Alexander Bala

DOI: https://doi.org/10.31004/edukatif.v4i1.2094

Isu, Rudolof Jibrael. 2021. "Pengaruh Upacara Rumah Adat Terhadap Ketertinggalan Pendidikan Anak Di Desa Oenbit." Retorika 2: 16-33.

Keraf, Goris. 2004. Komposisi Sebuah Pengantar Kemahiran Berbahasa. Ende: Nusa Indah.

Khoiri, Madhan. 2009. "Makna Simbol Dan Pergeseran Nilai Tradisi Upacara Adat Rebo Pungkasan." : 1-90. Http://Digilib.Uin-Suka.Ac.Id/3907/1/Bab I\%2cv\%2c Daftar Pustaka.Pdf.

Lokanawa, Petrus. 2013. "Agama Dan Pembentukan Cara Pandang Serta Perilaku Hidup Manusia." Humaniora 4(45): 790-99.

Manek, Agnes Odiyanti. 2021. "Makna Budaya Topa Ma Ta Auba Pada Masyarakat Desa Lasi , Kecamatan Kuanfatu, Kabupaten Timor Tengah Selatan." Retorika 2: 45-59.

Miles, M., \& Huberman, M. 1992. 5 Bmc Public Health Qualitative Data Analysis A Method Sourcebook Third Edition. California: Sage Publications Https://Ejournal.Poltektegal.Ac.Id/Index.Php/Siklus/Article/View/298\%0ahttp://Repositorio.Unan.Edu. Ni/2986/1/5624.Pdf\%0ahttp://Dx.Doi.Org/10.1016/J.Jana.2015.10.005\%0ahttp://Www.Biomedcentral.C om/1471-2458/12/58\%0ahttp://Ovidsp.Ovid.Com/Ovidweb.Cgi?T=Js\&P.

Muhidin, Rahmat. 2015. "Kosakata Budaya Yang Berhubungan Dengan Adat Perkawinan Melayu Bangka Di Kota Pangkalpinang." Widyaparwa 43(1): Http://Www.Widyaparwa.Com/Index.Php/Widyaparwa/Article/View/95.

Nur, Fadhilah, Aisyah, And Laili Etika Rahmawati. 2020. "Muatan Kearifan Lokal Pada Buku Bacaan Siswa Terbitan Kemdikbud.” Diglosia: Jurnal Kajian Bahasa, Sastra, Dan Pengajarannya 3(3): 317-30.

Ola, Simon Sabon. 2013. Buku Ajar Sosiolinguistik. Kupang: Lembaga Penelitian Undana.

Pampe, Pius. 2009. Alineansi Verbal Pada Umat Katolik Etnik Manggarai.

Rahyono, F.X. 2015. Kearifan Budaya Dalam Kata. Jakarta: Wedatama Wydia Sastra.

Riyanti, Dwi, Sabit Irfani, And Danang Prasetyo. 2022. "Pendidikan Berbasis Budaya Nasional Warisan Ki Hajar Dewantara." Edukatif: Jurnal Ilmu Pendidikan 4(1): 345-54.

Sibarani, Robert. 2015. "Pendekatan Antropolinguistik Terhadap Kajian Tradisi Lisan.” In Retorika: Jurnal Ilmu Bahasa, , 94-107.

Umri , Ulili, Ganefri, And Hadiyanto. 2021. "Perencanaan Pengembangan Dan Pendidikan Berbasis Kearifan Lokal.” Edukatif: Jurnal Ilmu Pendidikan 3(5): 2025-31. 